\title{
Stage I Pancreatic Cancer AJCC v6 and v7
}

National Cancer Institute

\section{Source}

National Cancer Institute. Stage I Pancreatic Cancer AJCC v6 and v7. NCI Thesaurus.

Code $C 7785$.

Stage I includes: IA (T1, N0, M0); IB (T2, N0, M0). T1: T umor limited to the pancreas 2 $\mathrm{cm}$ or less in greatest dimension. T2: Tumor limited to the pancreas, more than $2 \mathrm{~cm}$ in greatest dimension. N0: No regional lymph node metastasis. MO: No distant metastasis. (AJCC 6th and 7th Eds.) 